\title{
NILAI TUKAR, NILAI EKSPOR, DAN PERTUMBUHAN EKONOMI TERHADAP PROFITABILITAS EKSPORTIR FOOD AND BEVERAGE DI BEI
}

\author{
Ni Putu Eka Sari ${ }^{1}$ \\ I Gde Kajeng Baskara ${ }^{2}$
}
${ }^{1,2}$ Fakultas Ekonomi dan Bisnis Universitas Udayana, Bali, Indonesia e-mail: niputuekasari96@gmail.com

\begin{abstract}
ABSTRAK
Penelitian ini bertujuan untuk menguji signifikansi pengaruh nilai tukar rupiah, nilai ekspor, dan pertumbuhan ekonomi terhadap profitabilitas perusahaan ekspor food and beverage di Bursa Efek Indonesia. Sampel yang digunakan adalah perusahaan food and beverage di Bursa Efek Indonesia selama periode 2012-2016 dengan jumlah 6 perusahaan yang dikumpulkan melalui purposive sampling. Pengujian hipotesis penelitian menggunakan teknik analisis regresi linier berganda. Hasil penelitian ini menunjukkan bahwa : nilai tukar rupiah, nilai ekspor, dan pertumbuhan ekonomi berpengaruh positif dan signifikan terhadap profitablitas.
\end{abstract}

Kata kunci: nilai tukar, pertumbuhan ekspor, pertumbuhan ekonomi

\begin{abstract}
This study aims to examine the significance of the effect of rupiah exchange rate, export value, and economic growth on the profitability of food and beverage export companies in Indonesia Stock Exchange. The sample used is food and beverage company in Indonesia Stock Exchange during period 2012-2016 with 6 companies collected through purposive sampling. Hypothesis testing research using multiple linear regression analysis technique. The results of this study indicate that: exchange rate of Rupiah, export value, and economic growth have positive and significant effect to profitablity.
\end{abstract}

Keywords: exchange rate, export growth, economic growth 
Ni Putu Eka Sari dan I Gde Kajeng Baskara. Nilai Tukar, Nilai Ekspor, dan ...

\section{PENDAHULUAN}

Perdagangan internasional saat ini telah berkembang sangat pesat. Perkembangan tersebut dapat dilihat dari semakin banyaknya transaksi bisnis antar negara, misalnya pembelian barang dari satu negara dan mengirimkannya ke negara lain. Transaksi perdagangan internasional berbeda dengan transaksi perdagangan dalam negeri karena pada transaksi perdagangan internasional melibatkan beberapa negara (Griffin \& Pustay, 2005). Perbedaan dapat dilihat pada penggunaan mata uang, budaya, hukum serta ketersediaan sumber daya dalam setiap negara. Perbedaan dalam berbagai hal tentunya dapat mempengaruhi efektivitas bisnis. Efektivitas bisnis dapat dilihat dari laporan keuangan suatu bisnis.

Manajemen keuangan dalam perdagangan internasional perlu memperhatikan kinerja keuangan perusahaan saat melakukan transaksi internasional. Kinerja keuangan dalam perdagangan internasional sangat penting untuk diketahui guna menilai perusahaan tersebut dalam keadaan efisien atau tidak. Kegiatan perdagangan internasional terbagi menjadi dua yaitu impor dan ekspor. Kegiatan impor merupakan pembelian barang dan jasa dari luar negeri ke dalam negeri dengan perjanjian kerjasama antara dua negara atau lebih (Jimmy, 2013). Ekspor adalah pembelian negara lain atas barang buatan perusahaanperusahaan di dalam negeri (Sukirno, 2008: 205). Ekspor penting tidak hanya karena kekuatannya menghasilkan devisa tetapi juga dapat memperlihatkan peningkatan produktivitas perdagangan, yang telah dikonfirmasi dalam banyak penelitian (Lee dan Sanica, 2015). 
Analisis kinerja keuangan perusahaan ekspor sangat penting dilakukan dibandingkan dengan perusahaan impor mengingat kegiatan ekspor akan berdampak pada poduktivitas nasional. Selisih ekspor dengan impor akan berdampak pada surplus atau defisit neraca perdagangan sebuah negara.

Menganalisis kinerja keuangan perusahaan secara umum harus memperhatikan faktor-faktor yang dapat mempengaruhi kinerja perusahaan. Menurut Samsul (2006:200) terdapat berbagai faktor yang mempengaruhi kinerja keuangan perusahaan baik itu faktor makro maupun mikro. Faktor makro ekonomi adalah faktor-faktor yang mempengaruhi ekonomi secara keseluruhan yang berada di luar perusahaan yang mempunyai pengaruh terhadap kinerja saham maupun perusahaan baik secara langsung maupun tidak langsung, seperti tingkat bunga, tingkat inflasi, kurs valuta asing, peredaran uang, kebijakan pemerintah dan lain - lain, sedangkan faktor mikro ekonomi berada dalam perusahaan itu sendiri antara lain ditunjukkan oleh rasio keuangan perusahaan, seperti laba bersih per saham (Earning per Share/EPS), nilai buku per saham, rasio ekuitas terhadap utang (debt to equity ratio), rasio laba bersih terhadap utang (return on equity) dan lain - lain. Penilaian kinerja perusahaan dengan memperhatikan faktor makro sangat penting untuk dilakukan, untuk mengetahui kendala apa saja yang mungkin muncul serta risiko yang mungkin terjadi yang dapat mempengaruhi kinerja perusahaan.

Nilai tukar merupakan bagian dari faktor ekonomi makro yang dapat di analisis pengaruhnya terhadap kinerja keuangan perusahaan. Menurut Rodriguez dan Carter (2006 : 91), Nilai tukar adalah harga dari suatu mata uang yang 
Ni Putu Eka Sari dan I Gde Kajeng Baskara. Nilai Tukar, Nilai Ekspor, dan ...

dibandingkan dengan jenis mata uang lain. Pada perdagangan mata uang terdapat kurs beli dan kurs jual, kurs beli menunjukkan nilai tukar yang dinyatakan dalam jumlah satuan mata uang negara lain yang harus diserahkan kepada tempat penukaran uang untuk membeli tiap unit mata uang negara tertentu. Sedangkan, kurs jual menunjukkan jumlah satuan mata uang negara lain yang akan diterima dari pihak tempat penukaran uang, jika membeli mata uang lain dengan mata uang domestik.

Nilai tukar merupakan salah satu faktor penentu dalam profitabilitas dan penilaian efisiensi proyek investasi. Bahkan, pertukaran stabilitas tingkat mengarah ke ekonomi domestik yang aman dan akibatnya, investor dapat mengambil keputusan untuk berinvestasi saat ini dan di masa depan dengan mudah (Samimi et al., 2016).

Penurunan nilai tukar akan menyebabkan produk suatu perusahaan lebih kompetitif dipasar luar negeri, sehingga membuka peluang perusahaan untuk meningkatkan pendapatan yang lebih besar karena penjualan produknya semakin diminati di pasar luar negeri. Apalagi pendapatan yang diterima oleh perusahaan adalah dalam bentuk mata uang Dollar. Perusahaan yang operasinya menggunakan Dollar akan dipengaruhi, terutama perusahaan yang orientasi produknya dikhususkan untuk pasar ekspor atau luar negeri. Hal ini dapat mempengaruhi kinerja perusahaan.

Fajar dan Trikartika 2016 dalam penelitiannya menyatakan bahwa nilai koefisien nilai tukar berpengaruh negatif terhadap ROA. Hasibuan (2014) dalam penelitiannya menemukan nilai tukar berpengaruh negatif terhadap ROA. Nur 
2015 dalam penelitiannya juga menemukan bahwa nilai tukar berpengaruh negatif terhadap profitabilitas perusahaan dalam hal ini ROA, dengan asumsi variabel lain bernilai konstan atau tetap. Hasil Pujawati, Wiksuana, dan Artini (2015) dalam penelitian menunjukkan dengan melemahnya nilai tukar rupiah terhadap dolar akan memberikan dampak yang positif terhadap pendapatan yang akan diterima oleh perusahaan karena jumlah rupiah yang diterima oleh perusahaan akan semakin banyak apabila rupiah melemah terhadap dolar. Dengan demikian secara teoritis, nilai nilai tukar mata uang memiliki hubungan negatif dengan profitabilitas, demikian juga sebaliknya. Sementara itu penelitian lain oleh Tulunde et al. (2014) menemukan secara simultan menunjukan bahwa nilai tukar berpengaruh signifikan terhadap ROA. Sedangkan secara parsial nilai tukar berpengaruh secara positif terhadap ROA. Zamanian et al. (2017) efek ketidakpastian nilai tukar pada tingkat pengembalian perusahaan berorientasi ekspor positif baik dalam jangka pendek maupun jangka panjang; yang menyajikan bahwa semakin banyak ketidakpastian nilai tukar, semakin banyak tingkat pengembalian yang akan kita miliki dalam jangka panjang. Simiyu (2015) juga menemukan interaksi positif antara nilai tukar dengan profitabilitas. Ada juga penelitian yang menemukan tidak berpengaruhnya nilai tukar terhadap profitabilitas, yaitu Kiganda (2014)

Faktor lain yang perlu diperhatikan dalam menganalisis kinerja keuangan adalah pertumbuhan ekonomi suatu negara. Menurut Sukirno (2009:9), pertumbuhan ekonomi dapat didefinisikan sebagai perkembangan kegiatan dalam perekonomian yang menyebabkan barang dan jasa yang akan diproduksi oleh 
Ni Putu Eka Sari dan I Gde Kajeng Baskara. Nilai Tukar, Nilai Ekspor, dan ...

masyarakat mengalami peningkatan. Dalam pengukuran pertumbuhan maupun aktifitas perekonomian tersebut, salah satu alat ukur yang sering dipergunakan adalah Produk Domestik Bruto (PDB). Produk domestik bruto adalah nilai mata uang barang dan jasa yang diproduksi di suatu negara dalam suatu periode tertentu (Tuncay dan Cengiz, 2017). Penggunaan PDB dalam pengukuran pertumbuhan ini dianggap cukup memadai karena memiliki beberapa keunggulan dibandingkan dengan alternatif indikator lainnya. Nilai PDB dapat juga digunakan sebagai gambaran dari aktifitas perekonomian suatu negara pada suatu rentang waktu tertentu. Fluktuasi nilai PDB diakibatkan terjadinya fluktuasi dalam aktifitas perekonomian nyata dalam suatu wilayah negara pada suatu rentang waktu tertentu (Rinamenda, 2010).

Perkembangan perekonomian suatu negara tidak selalu berada pada suatu keadaan yang konstan. Perekonomian mengalami peningkatan maupun penurunan pertumbuhan yang merupakan gambaran pergerakan dari semua aktifitas yang dijalankan oleh unit-unit ekonomi yang ada di dalam suatu negara. Apabila aktifitas yang dilaksanakan unit-unit ekonomi secara keseluruhan menghasilkan peningkatan output maka perekonomian akan mengalami pertumbuhan demikian juga sebaliknya, sehingga perkembangan perekonomian mengalami variasi dari waktu ke waktu. Karena itu fase pertumbuhan ekonomi dapat dipandang juga sebagai fase aktifitas bisnis (Rinamenda, 2010).

Secara teoritis, pengaruh fluktuasi perekonomian berdampak pada keseluruhan perusahaan. Pertumbuhan ekonomi yang tinggi dapat meningkatkan profitabilitas perusahaan dan perubahan kondisi perekonomian secara makro akan 
mempengaruhi kinerja perusahaan. Kinerja perusahaan tersebut akan tercermin dari laba yang diperoleh oleh perusahaan tersebut. Walaupun pertumbuhan ekonomi suatu negara bukan merupakan satuu-satunya faktor yang mempengaruhi kinerja perusahaan, namun pertumbuhan ekonomi diduga menjadi faktor yang dominan dalam mempengaruhi kinerja tersebut, sehingga variabel ini menjadi fokus dalam penelitian yang akan dilaksanakan (Rinamenda, 2010).

Rinamenda (2010) dalam penelitiannya berpendapat pertumbuhan PDB sebesar berpengaruh positif terhadap ROA. Adiyadnya, Artini, Rahyuda (2016) menemukan bahwa pertumbuhan PDB berpengaruh positif signifikan terhadap profitabilitas perusahaan. Asrina (2015) dalam penelitiannya menemukan berpengaruh positif terhadap ROA.

Faktor ekonomi makro lain yang dapat mempengaruhi kinerja perusahaan dari sisi profitabilitasnya adalah nilai ekspor. Kinerja ekspor dapat dilihat dari laju pertumbuhan (nilai atau volume) ekspor. Namun demikian, nilai ekspor yang tinggi hanyalah satu sisi keberhasilan pengembangan ekspor suatu negara. Ekspor merupakan salah satu alternatif yang dapat menjadi pendorong perekonomian. Sesuai dengan teori ekonomi makro yang menyatakan ekspor neto dapat dijadikan sebagai alat pertumbuhan ekonomi (the engine of growth). Upaya mendorong ekspor dapat dimulai dengan melakukan berbagai kajian mengenai permasalahan ekspor. Pemahaman tentang permasalahan ekspor dapat ditindaklanjuti dengan berbagai upaya maupun kebijakan yang sesuai, sehingga hal ini diharapkan dapat menjadi pendorong untuk meningkatkan kinerja ekspor dari segi profitabilitasnya (Siregar dan Arief, 2005). 
Ni Putu Eka Sari dan I Gde Kajeng Baskara. Nilai Tukar, Nilai Ekspor, dan ...

Alatas (2015) dalam penelitiannya menemukan bahwa setiap kenaikan harga domestik akan menaikkan volume ekspor serta tidak ada pengaruh signifikan variabel harga domestik terhadap volume ekspor. Selain itu penambahan harga internasional akan menaikkan volume ekspor serta ada pengaruh signifikan variabel harga internasional terhadap volume ekspor. Berdasarkan hasil tersebut berarti bahwa harga berpengaruh positif terhadap volume ekspor. Setiap peningkatan harga tentunya akan mempengaruhi profitabilitas perusahaan ekspor, an kata lain jika harga meningkat dan volume ekspor meningkat maka akan berpengaruh terhadap profitabilitas karena dengan meningkatnya harga tentunya akan meningkatkan pendapatan yang berdampak pada profitabilitas.

Temuan Febriyanto (2012) dan Putra (2013) yang menyatakan bahwa volume produksi berdampak pada kinerja ekspor. Volume produksi sebagai pemasok kebutuhan industri dalam negeri sangat berdampak pada kinerja ekspor. Ketika volume produksi meningkat dan kebutuhan industri dalam negeri di anggap konstan maka ekspor juga akan meningkat. Peningkatan ekspor tentunya dapat meningkatkan pendapatan yang dapat mempengaruhi jumlah profitabilitas yang diperoleh. Volume produksi dalam negeri sebagai penyedia kebutuhan industri dan kebutuhan ekspor perlu didorong (Dana dan Hasan, 2016). Wagner (2011) dalam penelitinnya menunjukkan tidak ada pengaruh signifikan secara statistik dan secara ekonomi dari aktivitas perdagangan (salah satunya nilai ekspor) terhadap profitabilitas.

Berdasarkan uraian sebelumnya mengenai kinerja keuangan perusahaan ekspor diukur dari sisi profitabilitasnya yang dapat dipengaruhi oleh faktor 
ekonomi makro seperti nilai tukar, nilai ekspor, dan pertumbuhan ekonomi, maka penelitian ini menarik untuk dilakukan dengan judul "Pengaruh Nilai Tukar, Nilai Ekspor, dan Pertumbuhan Ekonomi terhadap Profitabilitas Perusahaan Ekspor Food and Beverage di BEI".

Penelitian ini bertujuan untuk mengetahui pengaruh nilai tukar, nilai ekspor, pertumbuhan ekonomi pada profitabilitas perusahaan ekspor. Sampel yang digunakan dalam penelitian ini adalah perusahaan ekspor food and beverage yang terdaftar di Bursa Efek Indonesia periode tahun 2012-2016.

Menurut Madura (2006:88) menyatakan bahwa "Nilai tukar atau kurs merupakan mengukur suatu valuta dari perspektif lain”. Berarti bahwa nilai tukar atau kurs merupakan ukuran harga perspektif valuta yang diekspresikan dari valuta lain. Penelitian terdahulu oleh Hasibuan (2014), Fajar dan Trikartika (2016) dalam penelitiannya menyatakan bahwa nilai tukar memiliki arah hubungan negatif terhadap profitabilitas. Hasil Pujawati, Wiksuana, dan Artini (2015) dalam penelitiannya menunjukkan nilai tukar mata uang memiliki hubungan negatif dengan profitabilitas. Sementara itu penelitian lain oleh Tulunde, Tommy, dan Van Rate (2014) secara parsial nilai koefisien regresi nilai tukar berpengaruh secara positif terhadap ROA. Simiyu (2015) juga menemukan interaksi positif antara nilai tukar dengan profitabilitas. Ada juga penelitian yang menemukan tidak berpengaruhnya nilai tukar terhadap profitabilitas, yaitu Kiganda (2014) Berdasarkan penelitian terdahulu dengan pendapat yang berbeda-beda, maka ditarik rumusan hipoteis sebagai berikut: 
Ni Putu Eka Sari dan I Gde Kajeng Baskara. Nilai Tukar, Nilai Ekspor, dan ...

$\mathrm{H}_{1} \quad$ : Semakin melemah nilai tukar rupiah terhadap dolar amerika berpengaruh positif signifikan terhadap profitabilitas perusahaan Ekspor Food and Beverage di Bursa Efek Indonesia.

Mankiw (2014: 170-171) menyatakan bahwa ekspor (exports) adalah barang dan jasa yang diproduksi di dalam negeri untuk dijual ke luar negeri. Ada sejumlah indikator yang dapat digunakan sebagai dasar informasi untuk mengkaji seberapa baik kinerja ekspor selama ini dan untuk memprediksi prospeknya kedepan. Salah satunya yang umum dipakai adalah pertumbuhan (nilai atau volume) ekspor rata-rata pertahun atau tren pertumbuhan jangka panjangnya. (Tulus Tambunan, $2004: 136)$.

Alatas (2015) dalam penelitiannya menemukan bahwa setiap penambahan harga internasional akan menaikkan volume ekspor serta ada pengaruh signifikan variabel harga internasional terhadap volume ekspor. Berdasarkan hasil tersebut berarti bahwa harga berpengaruh positif terhadap volume ekspor. Setiap peningkatan harga tentunya akan mempengaruhi profitabilitas perusahaan ekspor, dengan kata lain jika harga meningkat dan volume ekspor meningkat maka akan berpengaruh terhadap profitabilitas karena dengan meningkatnya harga tentunya akan meningkatkan pendapatan yang berdampak pada profitabilitas. Wagner (2011) dalam penelitinnya menunjukkan tidak ada pengaruh signifikan secara statistik dan secara ekonomi dari aktivitas perdagangan (salah satunya nilai ekspor) terhadap profitabilitas. Berdasarkan penelitian terdahulu dengan pendapat yang berbeda-beda, maka ditarik rumusan hipoteis sebagai berikut:

$\mathrm{H}_{2}$ : Nilai Ekspor berpengaruh positif signifikan terhadap profitabilitas perusahaan Ekspor Food and Beverage di Bursa Efek Indonesia. 
Mankiw (2003) menyatakan bahwa pertumbuhan ekonomi menunjukkan sejauh mana aktivitas perekonomian akan menghasilkan tambahan pendapatan masyarakat pada suatu periode tertentu. Karena pada dasarnya aktivitas perekonomian adalah suatu proses penggunaan faktor-faktor produksi untuk menghasilkan output, maka proses ini pada gilirannya akan menghasilkan suatu aliran balas jasa terhadap faktor produksi yang dimiliki masyarakat. Indikator yang digunakan untuk mengukur pertumbuhan ekonomi adalah tingkat pertumbuhan Produk Domestik Bruto (PDB).

Adiyadnya et al. (2016) menemukan bahwa nilai signifikansi yang lebih kecil dari 0,05 yaitu 0,000 dengan t hitung sebesar 6,917 artinya pertumbuhan PDB berpengaruh positif signifikan terhadap profitabilitas perusahaan. Asrina (2015) dalam penelitiannya berpendapat sebaliknya yaitu dengan nilai koefisien sebesar -5.51 mempunyai arti bahwa jika terjadi peningkatan PDB sebesar Rp.1,00 akan menyebabkan ROA turun sebesar 5.51. Berdasarkan penelitian terdahulu dengan pendapat yang berbeda-beda, maka ditarik rumusan hipoteis sebagai berikut:

$\mathrm{H}_{3} \quad$ : Pertumbuhan Ekonomi berpengaruh positif signifikan terhadap profitabilitas perusahaan Ekspor Food and Beverage di Bursa Efek Indonesia.

Berdasarkan penelusuran pada kajian pustaka dan hasil-hasil penelitian sebelumnya, maka model penelitian dalam penelitian ini adalah sebagai berikut: 


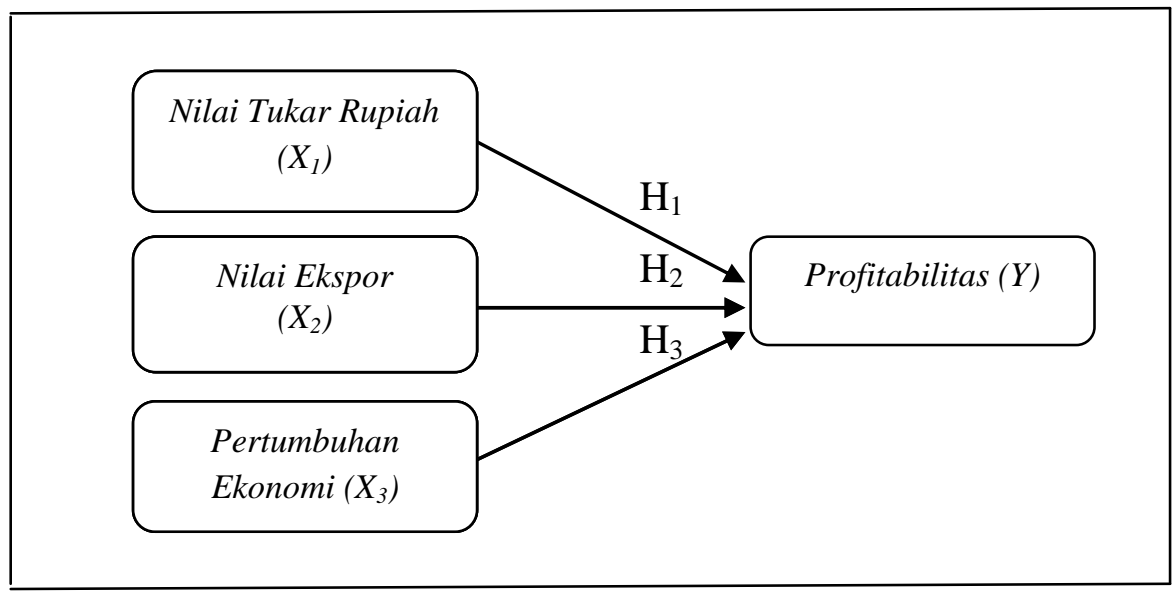

\section{Gambar 1. Kerangka Konseptual Penelitian}

\section{Nilai Tukar}

Pengertian nilai tukar mata uang menurut Dewan Standar Akuntansi Keuangan atau Financial Accounting Standards Board (FASB) adalah rasio antara suatu unit mata uang dengan sejumlah mata uang lain yang bisa ditukar pada waktu tertentu. Perbedaan nilai tukar riil dengan nilai tukar nominal penting untuk dipahami karena keduanya mempunyai pengaruh yang berbeda terhadap risiko nilai tukar (Sartono, 2001).

Rodriguez \& Carter (2006:91) menyatakan bahwa "exchange rate is the price hope one currency expresse in terms of another currency". Artinya bahwa nilai tukar adalah harga dari suatu mata uang yang dibandingkan dengan jenis mata uang lain. Menurut Madura (2006:88) menyatakan bahwa "Nilai tukar atau kurs merupakan mengukur suatu valuta dari perspektif lain". Berarti bahwa nilai tukar atau kurs merupakan ukuran harga perspektif valuta yang diekspresikan dari valuta lain.

\section{Nilai Ekspor}

Mankiw (2014: 170:171) menyatakan bahwa ekspor (exports) adalah barang dan jasa yang diproduksi di dalam negeri untuk dijual ke luar negeri. Ada 
sejumlah indikator yang dapat digunakan sebagai dasar informasi untuk mengkaji seberapa baik kinerja ekspor selama ini dan untuk memprediksi prospeknya kedepan. Salah satunya yang umum dipakai adalah pertumbuhan (nilai atau volume) ekspor rata-rata pertahun atau tren pertumbuhan jangka panjangnya. Dasar pemikiran dari penggunaan indikator ini adalah sebagai berikut : kinerja ekspor yang baik dicerminkan salah satunya laju pertumbuhan rata-rata per tahunnya yang relatif tinggi dibandingkan Negara-negara pesaingnya, atau oleh tren pertumbuhan jangka panjangnya yang positif (meningkat). Tren pertumbuhan jangka panjang yang meningkat dari ekspor dari suatu produk mencerminkan perubahan jangka panjang dari tingkat daya saing dari produk tersebut di dalam perdagangan global. (Tulus Tambunan, 2004 : 136).

\section{Pertumbuhan Ekonomi}

Mankiw (2003) menyatakan bahwa pertumbuhan ekonomi menunjukkan sejauh mana aktivitas perekonomian akan menghasilkan tambahan pendapatan masyarakat pada suatu periode tertentu. Karena pada dasarnya aktivitas perekonomian adalah suatu proses penggunaan faktor-faktor produksi untuk menghasilkan output, maka proses ini pada gilirannya akan menghasilkan suatu aliran balas jasa terhadap faktor produksi yang dimiliki masyarakat.

Indikator yang digunakan untuk mengukur pertumbuhan ekonomi adalah tingkat pertumbuhan Produk Domestik Bruto (PDB). Ada beberapa alasan yang mendasari pemilihan pertumbuhan ekonomi menggunakan Produk Domestik Bruto (PDB) bukan indikator lainnya di antaranya adalah bahwa PDB merupakan jumlah nilai tambah yang dihasilkan oleh seluruh aktivitas produksi di dalam 
Ni Putu Eka Sari dan I Gde Kajeng Baskara. Nilai Tukar, Nilai Ekspor, dan ...

perekonomian, hal ini berarti peningkatan PDB juga mencerminkan peningkatan balas jasa kepada faktor-faktor produksi yang digunakan dalam aktivitas produksi tersebut.(Mankiw, 2003).

\section{METODE PENELITIAN}

Lokasi penelitian dalam penelitian ini adalah di Bursa Efek Indonesia (BEI) pada perusahaan Ekspor Food and Beverage pada tahun 2012 - 2016. Jenis data yang digunakan dalam penelitian ini adalah data laporan keuangan perusahaan ekspor food and beverage di Bursa Efek Indonesia, perkembangan nilai tukar, pertumbuhan ekonomi, dan pertumbuhan ekspor tahun 2012-2016 diperoleh dari situs resmi Badan Pusat Statistik, dan web kementrian perdagangan.

Populasi dari penelitian ini adalah seluruh perusahaan food and beverage pada situs resmi Bursa Efek Indonesia tahun 2012-2016. Sampel dalam penelitian ini adalah seluruh perusahaan ekspor food and beverage di Bursa Efek Indonesia tahun 2012-2016. Penelitian ini menggunakan teknik purposive sampling. Metode pengumpulan data dalam penelitian ini menggunakan metode studi observasi yaitu dokumentasi berdasarkan laporan keuangan perusahaan yang telah dipublikasikan di situs resmi Bursa Efek Indonesia.

Profitabilitas (Y) dalam penelitian ini diukur dengan menggunakan return on assets (ROA) pada perusahaan ekspor food and beverage di Bursa Efek Indonesia tahun 2012-2016. ROA adalah perbandingan antara laba bersih dengan total aktiva kemudian dikalikan seratus persen dengan rumus sebagai berikut:

$$
\mathrm{ROA}=\frac{\text { Laba Bersih }}{\text { Total Aktiva }} \times 100 \%
$$


Nilai tukar rupiah $\left(\mathrm{X}_{1}\right)$ merupakan rasio antara suatu unit mata uang dengan sejumlah mata uang lain yang bisa ditukar pada waktu tertentu. Perhitungan kurs rupiah dalam penelitian ini yaitu kurs rupiah dihitung setiap tahun dari tahun 2012 sampai dengan tahun 2016 dengan pengambilan data melalui website kementrian perdagangan data yang bersumber dari Badan Pusat Statistik (BPS) kurs rupiahdolar dalam penelitian ini menggunakan data rata-rata kurs tengah rupiah terhadap dolar dengan satuan ukuran rupiah.

Nilai ekspor adalah nilai seluruh barang dan jasa yang diperdagangkan ke luar negeri yang ditentukan oleh permintaan luar negeri. Nilai ekspor dalam penelitian ini yaitu nilai ekspor dari tahun 2012 sampai dengan tahun 2016 dengan pengambilan data melalui situs kementrian perdagangan serta data yang bersumber dari BPS.

Pertumbuhan ekonomi dapat diartikan perkembangan kegiatan dalam perekonomian yang menyebabkan barang dan jasa yang diproduksi dalam masyarakat bertambah dan kemakmuran masyarakat meningkat. Penelitian menghitung nilai pertumbuhan ekonomi berdasarkan Produk Domestik Bruto (PDB ) berdasarkan harga konstan 2010 yang digunakan adalah PDB rill dan untuk analisis data digunakan data perubahan PDB dengan satuan ukurannya adalah persentase $(\%)$.

$$
\mathrm{PDBt}=\frac{\mathrm{PDEt}-\mathrm{PDEt}-1}{\mathrm{PDEt}-1} \mathrm{x} 100 \%
$$

Analisis penelitian ini menggunakan uji asumsi klasik yang dilakukan sebelum model regresi linier berganda digunakan. Uji asumsi klasik meliputi uji multikolinearitas, uji heteroskedastisitas, uji autokorelasi, dan uji normalitas. Uji 
Ni Putu Eka Sari dan I Gde Kajeng Baskara. Nilai Tukar, Nilai Ekspor, dan ...

multikolinearitas digunakan untuk mengetahui adanya hubungan linier antar variabel independen dalam model regresi. Perasyaratan yang harus terpenuhi dalam model regresi adalah tidak adanya multikolinearitas. Pada umumnya jika VIF lebih besar dari 10, maka variabel tersebut mempunyai persoalan multikolinearitas dengan variabel bebas lainnya. Uji heteroskedastisitas digunakan untuk mengetahui ada tidaknya penyimpangan asumsi klasik heteroskedastisitas. Uji Autokorelasi digunakan untuk mengetahui ada atau tidaknya penyimpangan asumsi klasik autokorelasi, yaitu korelasi yang terjadi antara residual pada satu pengamatan dengan pengamatan lain pada model regresi. Perasyaratan yang harus terpenuhi adalah tidak adanya autokorelasi dalam model regresi. Metode pengujian yang sering digunakan adalah dengan Uji Durbin-Watson (uji DW) dengan ketentuan sebagai berikut : Angka D $-\mathrm{W}$ di bawah -2 berarti ada autokorelasi negatif, Angka D $-\mathrm{W}$ dari -2 sampai +2 berarti tidak ada autokorelasi., Angka D $-\mathrm{W}$ di atas +2 berarti ada autokorelasi positif. Untuk menguji apakah data yang digunakan normal atau tidak dapat dilakukan dengan uji Kolmogorov-Smirnov dengan melihat Asymp. (2-tailed). Jika nilai Asymp. (2tailed) lebih besar dari taraf signifikansi yang ditetapkan yaitu 5 persen $(0,05)$, maka data telah berdistribusi normal.

Analisis regresi linier berganda adalah hubungan secara linier antara dua atau lebih variabel independen $\left(\mathrm{X}_{1}, \mathrm{X}_{2}, \mathrm{X}_{3}, \ldots, \mathrm{Xn}\right)$ dengan variabel dependen $(\mathrm{Y})$. Analisis ini untuk mengetahui arah hubungan antara variabel independen dengan variabel dependen apakah masing-masing variabel independen berhubungan positif atau negatif dan untuk memprediksi nilai dari variabel dependen apabila 
nilai variabel independen mengalami kenaikan atau penurunan. Data yang digunakan biasanya berskala interval atau rasio. Persamaan yang digunakan dalam penelitian ini yaitu :

$$
\mathrm{Y}=\mathrm{a}+\mathrm{b}_{1} \mathrm{X}_{1}+\mathrm{b}_{2} \mathrm{X}_{2}+\mathrm{b}_{3} \mathrm{X}_{3}+\varepsilon
$$

\section{HASIL DAN PEMBAHASAN}

Penelitian ini bertujuan untuk mengetahui signifikansi pengaruh nilai tukar rupiah, nilai ekspor, dan pertumbuhan ekonomi terhadap profitabilitas (ROA) perusahaan food and beverage di Bursa Efek Indonesia periode 2012-2016. Perusahaan food and beverage merupakan salah satu kategori sektor industri di Bursa Efek Indonesia (BEI). Perusahaan makanan dan minuman merupakan perusahaan yang bergerak dibidang pembuatan produk kemudian dijual guna memperoleh keuntungan yang besar. Untuk mencapai tujuan tersebut diperlukan manajemen dengan tingkat efektifitas yang tinggi. Pengukuran tingkat efektifitas manajemen yang ditunjukkan oleh laba yang dihasilkan dari penjualan dan dari pendapatan investasi, dapat dilakukan dengan mengetahui seberapa besar rasio profitabilitas yang dimiliki (Brigham dkk., 2011).

Tabel 1.

Perusahaan Ekspor Food And Beverage Yang Menjadi Sampel Penelitian

\begin{tabular}{|c|c|c|}
\hline No & Kode Perusahaan & Nama Perusahaan \\
\hline 1 & AISA & Tiga Pilar Sejahtera Food Tbk, PT \\
\hline 2 & CEKA & Wilmar Cahaya Kalbar Tbk, PT \\
\hline 3 & ICBP & Indofood CBP Sukses Makmur Tbk, PT \\
\hline 4 & MLBI & Multi Bintang Indonesia Tbk, PT \\
\hline 5 & MYOR & Mayora Indah Tbk, PT \\
\hline 6 & INDF & Indofood Sukses Makmur Tbk, PT \\
\hline
\end{tabular}


Ni Putu Eka Sari dan I Gde Kajeng Baskara. Nilai Tukar, Nilai Ekspor, dan ...

Berdasarkan laporan keuangan tahunan yang di dapat dari www.kemendag.go.id maka diperoleh hasil analisis statistik deskriptif yang disajikan pada Tabel 2. Statistik deskriptif disajikan untuk memberikan informasi mengenai karakteristik variabel-variabel penelitian, antara lain nilai minimum, maksimum, rata-rata, dan deviasi standar. Rata-rata (mean) merupakan cara paling umum digunakan untuk mengukur nilai sentral dari suatu distribusi data. Deviasi standar menunjukkan seberapa luas atau rentangan antara nilai minimum dengan nilai maksimum dari masing-masing variabel. Output statistik deskriptif diolah dengan menggunakan Statistical Product and Service Solutions (SPSS) 18.0. Adapun hasil statistik deskriptif setiap variabel dapat dilihat pada tabel 2 berikut.

Tabel 2.

Hasil Uji Statistik Deskriptif

\begin{tabular}{lrrrrr}
\hline & N & Minimum & Maximum & \multicolumn{1}{c}{ Mean } & \multicolumn{1}{c}{ Std. Deviation } \\
\hline X1 & 30 & 9419.00 & 13511.64 & 11757.8120 & 1593.54006 \\
\hline X2 & 30 & 12530.53 & 15835.02 & 14314.6060 & 1236.81791 \\
\hline X3 & 30 & 4.88 & 6.03 & 5.3000 & .44086 \\
\hline Y & 30 & 3.19 & 65.72 & 12.5280 & 13.56208 \\
\hline Valid N (listwise) & 30 & & & & \\
\hline
\end{tabular}

Sumber : Data diolah, 2017

Nilai minimum variabel nilai tukar rupiah adalah Rp. 9.419 pada tahun 2012 dan nilai maksimum adalah Rp. 13.511,64 pada tahun 2015. Nilai rata-rata variabel nilai tukar rupiah adalah Rp. 11.758 dengan standar deviasi 1593.5.

Nilai minimum variabel nilai ekspor adalah Rp. 12.530,53 pada tahun 2015 dan nilai maksimum adalah Rp. $15.835,02$ pada tahun 2012. Nilai rata-rata variabel nilai ekspor adalah Rp. 14.314,6 dengan standar deviasi 1.236,8. 
Nilai minimum variabel pertumbuhan ekonomi adalah $4,88 \%$ pada tahun 2015 dan nilai maksimum adalah 6,03\% pada tahun 2012. Nilai rata-rata variabel pertumbuhan ekonomi adalah 5,3\% dengan standar deviasi 0.44086 .

Nilai minimum variabel ROA adalah $3.19 \%$ pada perusahaan Wilmar Cahaya Indonesia Tbk, PT tahun 2014 dan nilai maksimum adalah $65.72 \%$ pada perusahaan Multi Bintang Indonesia Tbk, PT tahun 2013. Nilai rata-rata variabel pertumbuhan ekonomi adalah $12.52867 \%$ dengan standar deviasi 13.56208 .

Uji asumsi klasik dilakukan dengan tujuan untuk memastikan hasil yang diperoleh memenuhi asumsi dasar di dalam analisis regresi. Hasil uji asumsi klasik yang dilakukan dalam penelitian ini adalah uji normalitas, uji multikoliniearitas dan uji heteroskedastisitas.

Tabel 3. Hasil Uji Multikolinearitas

\begin{tabular}{|c|c|c|}
\hline \multirow[t]{2}{*}{ Model } & \multicolumn{2}{|c|}{ Colinearity Statistic } \\
\hline & Tolerance & VIF \\
\hline $\mathrm{X} 1$ & 0,343 & 5,480 \\
\hline $\mathrm{X} 2$ & 0,311 & 2,621 \\
\hline $\mathrm{X} 3$ & 0,309 & 4,834 \\
\hline
\end{tabular}

Prasyarat yang harus terpenuhi dalam model regresi adalah tidak adanya multikolinearitas. Pada umumnya jika VIF lebih besar dari 10, maka variabel tersebut mempunyai persoalan multikolinearitas dengan variabel bebas lainnya. Berdasarkan hasil analisis, dapat dilihat bahwa nilai VIF semua variabel lebih kecil dari 10. Hasil ini mengindikasikan bahwa tidak terdapat gejala multikolinear dari model regresi yang dibuat. 
Tabel 4.

Hasil Uji Heteroskedastisitas

\begin{tabular}{ccc}
\hline Model & Sig. & Keterangan \\
\hline X1 & 0,900 & Lolos Uji \\
\hline X2 & 0,759 & Lolos Uji \\
\hline X3 & 0,815 & Lolos Uji \\
\hline
\end{tabular}

Sumber : Data diolah, 2017

Untuk mengetahui ada atau tidaknya heteroskedastisitas yaitu dengan melakukan Uji Glejser dengan meregresi nilai absolut terhadap variabel independen, dengan ketentuan jika nilai signifikan di atas 0,05 maka memiliki arti tidak terjadi heteroskedastisitas. Hasil uji menunjukkan nilai signifikansi lebih besar dari 0,05 yang artinya model regresi bebas dari gejala heteroskedastisitas.

Tabel 5.

Hasil Uji Autokorelasi

\begin{tabular}{|c|c|c|c|c|c|}
\hline Model & $\mathrm{R}$ & R Square & $\begin{array}{c}\text { Adjusted R } \\
\text { Square } \\
\end{array}$ & $\begin{array}{c}\text { Std. Error of the } \\
\text { Estimate }\end{array}$ & Durbin-Watson \\
\hline 1 & $.268^{\mathrm{a}}$ & .321 & .372 & 4.17221 & 1.842 \\
\hline
\end{tabular}
melakukan Uji Durbin-Watson (DW). Angka DW dari -2 sampai +2 berarti tidak ada autokorelasi. Hasil pengujian menunjukkan bahwa nilai DW sebesar 1,842 yang artinya tidak ada autokorelasi dalam model regresi.

Tabel 6.

Hasil Uji Normalitas

\begin{tabular}{lc}
\hline & Unstandardized Residual \\
\hline $\mathrm{N}$ & 30 \\
\hline Asymp. Sig. (2-tailed) & 0,087 \\
\hline Sumber : Data diolah, 2017 &
\end{tabular}

Untuk menguji apakah data yang digunakan normal atau tidak dapat dilakukan dengan menggunakan uji Kolmogorov-Smirnov dengan melihat nilai Asymp. Sig. (2-tailed). Jika nilai Asymp. Sig. (2-tailed) lebih besar taraf 
signifikansi yang ditetapkan yaitu 5 persen $(0,05)$, maka data telah berdistribusi normal. Berdasarkan hasil analisis, diperoleh hasil sebesar 0,087 > 0,05 yang artinya data berdistribusi normal.

Tabel 7.

Hasil Uji Analisis Regresi Linier Berganda

\begin{tabular}{|c|c|c|c|c|c|}
\hline \multirow[t]{2}{*}{ Model } & \multicolumn{2}{|c|}{ Unstandardized Coefficients } & \multirow{2}{*}{$\begin{array}{c}\begin{array}{c}\text { Standardized } \\
\text { Coefficients }\end{array} \\
\text { Beta }\end{array}$} & \multirow[t]{2}{*}{$\mathbf{t}$} & \multirow[t]{2}{*}{ Sig. } \\
\hline & B & Std. Error & & & \\
\hline (Constant) & 5,430 & 2,877 & & 3,013 & 0,090 \\
\hline $\mathrm{X} 1$ & 0,701 & 0,092 & 0,024 & 2,817 & 0,038 \\
\hline $\mathrm{X} 2$ & 0,934 & 0,073 & 0,056 & 3,961 & 0,021 \\
\hline X3 & 0,588 & 0,877 & 0,069 & 2,492 & 0,029 \\
\hline $\mathrm{R}$ & 0,268 & & & & \\
\hline $\mathrm{R}^{2}$ & 0,321 & & & & \\
\hline Adjusted $\mathrm{R}^{2}$ & 0,372 & & & & \\
\hline F hitung & 7,349 & & & & \\
\hline Sig. F & 0,002 & & & & \\
\hline
\end{tabular}

Analisis regresi linier berganda digunakan untuk mengetahui pengaruh antara variabel bebas terhadap variabel terikat. Dalam penelitian ini analisis regresi linier berganda digunakan untuk mengetahui besarnya pengaruh nilai tukar rupiah, nilai ekspor, dan pertumbuhan ekonomi terhadap return on assets (ROA) perusahaan food and beverge di Bursa Efek Indonesia tahun 2012-2016.

Persamaan regresi yang digunakan dalam penelitian ini dapat ditulis sebagai berikut:

$$
Y=5,430+0,701 X_{1}+0,934 X_{2}+0,588 X_{3}
$$

Besarnya nilai adjusted R square pada Tabel 6 adalah sebesar 0,372 yang artinya sebesar 37,2 persen variasi kinerja keuangan perusahaan dipengaruhi oleh nilai tukar rupiah, nilai ekspor dan pertumbuhan ekonomi, sedangkan sisanya sebesar 62,8 persen dipengaruhi oleh faktor-faktor lain yang tidak dimasukkan ke dalam model penelitian. 
Ni Putu Eka Sari dan I Gde Kajeng Baskara. Nilai Tukar, Nilai Ekspor, dan ...

\section{Pengaruh Nilai Tukar terhadap Profitabilitas Perusahaan Food And Beverage Periode 2012-2016}

Hasil penelitian menunjukkan bahwa variabel nilai tukar rupiah memiliki nilai signifikansi 0,038 yang lebih kecil dari 0,05 . Hasil ini berarti nilai tukar rupiah berpengaruh positif dan signifikan terhadap profitabilitas perusahaan. Hasil tersebut dapat diinterpretasikan bahwa nilai tukar rupiah berpengaruh positif dan signifikan terhadap profitabilitas (ROA) perusahaan food and beverage di Bursa Efek Indonesia periode tahun 2012-2016. Penelitian ini menunjukkan bahwa melemahnya nilai tukar rupiah terhadap dolar berpegaruh positif terhadap profitabilitas perusahaan ekspor food and beverage di Bursa Efek Indonesia. penurunan nilai tukar rupiah terhadap mata uang asing (US\$) memungkinkan eksportir menawarkan barang dengan harga yang lebih murah sehingga meningkatkan daya saing di luar negeri. Meningkatmya daya saing tersebut mendorong peningkatan pendapatan ekprostir. Hasil penelitian ini tidak mendukung penelitian dari Fajar dan Trikartika (2016), Nur (2015) dalam penelitiannya menemukan bahwa nilai tukar berpengaruh negatif terhadap profitabilitas perusahaan dalam hal ini ROA. Sebaliknya penelitian ini menudkung penelitian Tulunde, Tommy, dan Van Rate (2014), Simiyu (2015) menemukan interaksi positif antara nilai tukar dengan profitabilitas.

Pengaruh Nilai Ekspor terhadap Profitabilitas Perusahaan Food And Beverage Periode 2012-2016

Hasil penelitian menunjukkan bahwa variabel nilai ekspor memiliki nilai signifikansi 0,021 yang lebih kecil dari 0,05. Hasil ini berarti nilai ekspor 
berpengaruh positif dan signifikan terhadap profitabilitas perusahaan. Hasil tersebut dapat diinterpretasikan bahwa nilai ekspor berpengaruh positif dan signifikan terhadap profitabilitas (ROA) perusahaan food and beverage di Bursa Efek Indonesia periode tahun 2012-2016. Hasil penelitian ini menujukkan bahwa peningkatan nilai ekspor dapat meningkatkan profitabilitas karena ketika nilai ekspor meningkat menunjukkan ekspor suatu perusahaan yang semakin berkembang, dengan demikian tentunya akan meningkatkan return perusahaan yang akan berpengaruh terhadap profitabilitas. Hasil penelitian ini mendukung penelitian Alatas (2015) dalam penelitiannya menemukan bahwa setiap penambahan harga internasional akan menaikkan volume ekspor serta ada pengaruh signifikan variabel harga internasional terhadap volume ekspor. Berdasarkan hasil tersebut berarti bahwa harga berpengaruh positif terhadap volume ekspor. Setiap peningkatan harga tentunya akan mempengaruhi profitabilitas perusahaan ekspor, dengan kata lain jika harga meningkat dan volume ekspor meningkat maka akan berpengaruh terhadap profitabilitas karena dengan meningkatnya harga tentunya akan meningkatkan pendapatan yang berdampak pada profitabilitas. Penelitian ini juga mendukung penelitian Bausch dan Krist (2007) yang menemukan bahwa terdapat hubungan positif signifikan secara statistik antara perusahaan internasional terhadap kinerja keuangan. Hasil penelitian ini tidak mendukung penelitian dari Wagner (2011) dalam penelitinnya menunjukkan tidak ada pengaruh signifikan secara statistik dan secara ekonomi dari aktivitas perdagangan (salah satunya nilai ekspor) terhadap profitabilitas. 
Ni Putu Eka Sari dan I Gde Kajeng Baskara. Nilai Tukar, Nilai Ekspor, dan ...

\section{Pengaruh Pertumbuhan Ekonomi terhadap Profitabilitas Perusahaan Food And Beverage Periode 2012-2016}

Hasil penelitian menunjukkan bahwa variabel variabel pertumbuhan ekonomi memiliki nilai signifikansi 0,029 yang lebih kecil dari 0,05. Hasil ini berarti pertumbuhan ekonomi berpengaruh positif dan signifikan terhadap profitabilitas perusahaan. Hasil tersebut dapat diinterpretasikan bahwa pertumbuhan ekonomi berpengaruh positif dan signifikan terhadap profitabilitas (ROA) perusahaan food and beverage di Bursa Efek Indonesia periode tahun 2012-2016. Hasil penelitian ini menunjukkan bahwa pertumbuhan ekonomi dapat berpengaruh positif terhadap profitabilitas karena ketika pertumbuhan ekonomi meningkat berarti bahwa telah terjadi peningkatan aktivitas dan kegiatan perekonomian. Meningkatnya aktivitas dan kegiatan perekonomian akan meningkatkan barang dan jasa yang diproduksi oleh masyarakat juga meningkat. Perusahaan ekspor sebagai penyedia barang dan jasa tentunya akan mengalami peningkatan apabila terjadi peningkatan pertumbuhan ekonomi. Hasil penelitian ini mendukung penelitian Rinamenda (2010), Adiyadnya, Artini, Rahyuda (2016) menemukan pertumbuhan PDB berpengaruh positif signifikan terhadap profitabilitas perusahaan. Sebaliknya penelitian ini tidak mendukung penelitian Asrina (2015) dalam penelitiannya berpendapat dengan nilai koefisien sebesar 5.51 mempunyai arti bahwa jika terjadi peningkatan PDB sebesar Rp.1,00 akan menyebabkan ROA turun sebesar 5.51. 


\section{SIMPULAN DAN SARAN}

Berdasarkan hasil analisis data maka dapat ditarik kesimpulan yaitu nilai tukar rupiah berpengaruh positif dan signifikan terhadap profitabilitas (ROA) perusahaan food and beverage di Bursa Efek Indonesia periode tahun 2012-2016. Nilai ekspor berpengaruh positif dan signifikan terhadap profitabilitas (ROA) perusahaan food and beverage di Bursa Efek Indonesia periode tahun 2012-2016. Pertumbuhan ekonomi berpengaruh positif dan signifikan terhadap profitabilitas (ROA) perusahaan food and beverage di Bursa Efek Indonesia periode tahun 2012-2016.

Bagi penelitian selanjutnya, disarankan untuk menggunakan objek yang lebih luas, tidak hanya pada perusahaan food and beverage saja tetapi juga perusahaan-perusahaan di sektor lainnya. Disamping itu diharapkan untuk mempertimbangkan hasil penelitian ini khususnya dalam pengembangan manajemen keuangan internasional, karena dari hasil penelitian terbukti faktorfaktor tersebut berpengaruh positif signifikan terhadap proitabilitas perusahaan ekspor food and beverage.

Bagi pemerintah dalam menentukan kebijakan nantinya perlu memperhatikan faktor-faktor makro ekonomi seperti nilai tukar, nilai ekspor, dan pertumbuhan ekonomi, karena dari hasil penelitian terbukti faktor-faktor tersebut berpengaruh positif signifikan terhadap profitabilitas perusahaan ekspor food and beverage. 


\section{REFERENSI}

Adiyadnya Sidhi I Nyoman, Artini Sri Luh Gede, dan Rahyuda Henny. 2016. Pengaruh Beberapa Variabel Ekonomi Makro Terhadap Profitabilitas Dan Return Saham Pada Industri Perbankan Di BEI. E-Jurnal Ekonomi dan Bisnis Universitas Udayana, 5 (8), 2687-2588.

Alatas Andi. 2015. Trend Produksi dan Ekspor Minyak Sawit (CPO) Indonesia. Jurnal Agraris, 1 (2), 121-122.

Asrina Putri. 2015. Analisis Pengaruh Pdb, Nilai Tukar Rupiah, Non Performing Finance (Npf), Bopo Terhadap Profitabilitas (Roa) Perbankan Syariah Di Indonesia Periode 2008-2013. Jom FEKON, 2 (1), 4-9.

Bausch, Andreas and Mario Krist (2007), The Effect of Context-Related Moderators on the Internationalization-Performance Relationship: Evidence from Meta- Analysis. Management International Review 47(3), 319-347.

Brigham, Eugene F., dan Joel F Houston. 2011. Dasar-Dasar Manajemen Keuangan. Buku 1. Jakarta: Salemba Empat.

Case, Karl E., Fair, Ray C. 2007. Prinsip-prinsip Ekonomi. Edisi kedelapan. Penerbit Erlangga. Jakarta.

Dana Badara Shofi, Achmad Fawaid Hasan. 2016. Analisis Kinerja Ekspor Tembakau Di Indonesia: Pendekatan Vector Autoregression. Dinamika Global : Rebranding Keunggulan Kompetitif Berbasis Kearifan Lokal FEB

Dunning, John H. (1993). Multinational Enterprises and the Global Economy, England: Addison-Wesley

Fahmi, Irham. 2011. Analisis Kinerja Keuangan: Panduan Bagi Akademisi, Manajer, Dan Investor Untuk Menilai Dan Menganalisis Bisnis Dari dampak Aspek Keuangan. Bandung: Alfabeta.

Fajar Aditya P M, Irni Yunita, Tieka Trikartika G. 2016. Analisis Pengaruh Inflasi, Nilai Tukar, Dan Suku Bunga Bi Terhadap Profitabilitas Perusahaan (Studi Pada Perusahaan Telekomunikasi Yang Terdaftar Di Bei Periode 2010-2014). e-Proceeding of Management. 3(1), 291-292.

Febriyanto. 2012. Analisis faktor-faktor yang mempengaruhi ekpor tembakau (nicotina tabacum) di jawa tengah. Surakarta: Universitas Sebelas Maret Surakarta 
Griffin, Ricky W. and Pustay, Michael W., 2005. Bisnis Internasional (Alih. Bahasa Yohanes S. Indrakusuma). Jilid 1 dan 2, Jakarta: PT Indeks.

Haghiri, Amir, 2012. The Investigation of Effective Factors on Stock Return with Emphasis on ROA and ROE Ratios in Tehran stock exchange (TSE). Journal of Basic and Applied Scientific Research, 2(9)9097-9103.

Hasibuan Bosar. 2014. Pengaruh Tingkat Inflasi, Suku Bunga Dan Nilai Tukar Terhadap Kinerja Keuangan Perusahaan Perbankan Yang Listing Di Bursa Efek Indonesia Periode Tahun 2008 - 2012. Jurnal Measurement, 8 (2), 3842.

Haque, S. 2013. The Performance Analysis of Private Conventional Bank: A Case Study of Bangladesh. Journal of Business and Management, 12 (1), 19-25.

Hernendiastro, Andre. 2005. Pengaruh Kinerja Perusahaan dan Kondisi Ekonomi Terhadap Return Saham dengan Metode Intervalling (Studi Kasus pada Sham-Saham LQ45). Tesis Sarjana S-2 Program Studi Magister Manajemen Universitas Diponogoro, Semarang.

Hutabarat, R. 1996. Transaksi Ekspor Impor. Erlangga. Jakarta.

Jimmy Benny. 2013. Ekspor Dan Impor Pengaruhnya Terhadap Posisi Cadangan Devisa Di Indonesia. Jurnal EMBA, 1(4), 1406-1415.

Jung, M. and Keun Lee, (2010) Sectoral systems of innovation and productivity catch-up: determinants of the productivity gap between Korean and Japanese firms, Industrial and Corporate Change 19(4), 1037-1069.

Kamstra, Mark., Peter Kennedy., dan Teck-Kin Suan. 2001. Combining Bond Rating Forecasts Using Logit. 2001. The Financial Review, 36 (2), 75-96.

Kasmir. 2010. Analisis Laporan keuangan. Ed 1, Jakarta : Rajawali

Keown. Athur J. 2008. Manajemen Keuangan. Edisi 10. Jakarta: PT Macanan Jaya Cemerlang.

Kiganda, Evans Ovamba. 2014. Effect of Macroeconomic Factors on Commercial Banks Profitability in Kenya: Case of Equity Bank Limited. Journal of Economics and Sustainable Development, 5 (2), 46-56.

Kuncoro, Mudrajad dan Suhardjono. 2009. Manajemen Perbankan: Teori dan Aplikasi. Yogyakarta: BPFE. 
Ni Putu Eka Sari dan I Gde Kajeng Baskara. Nilai Tukar, Nilai Ekspor, dan ...

Kusuma, Indra Wijaya. 1999. Financial Performances and Characteristic: Comparisons of U.S Multinational and Domestics Firms. Gadjah Mada International Journal of Business, 1(1), 11-28.

Lee Keun, Ramanayake Sanica Sulochani. 2015. Does openness lead to sustained economic growth? Export growth versus other variables as determinants of economic growth. Forthcoming in Journal of the Asia-Pacific Economy (august 2015), 10(10), 8-14.

Madura, Jeff. 2006. 2012. Keuangan Perusahaan Internasional. Buku satu, Edisi Kedelapan, Terjemahan Yanivi S. Bachtiar, Jakarta: Salemba Empat.

Mankiw G, Euston Q, Peter W. 2003. Pengantar Ekonomi Makro. Jakarta Selatan: Salemba Empat.

Mankiw G, Euston Q, Peter W. 2014. Pengantar Ekonomi Makro. Jakarta Selatan: Salemba Empat.

Mohamad Samsul. 2006. Pasar Modal dan Manajemen Portofolio. Erlangga, Jakarta.

Munawir, S. 2002. Analisis Laporan Keuangan. Edisi 2. Yogyakarta:Liberty.

Pujawati Putu Eka, I Gusti Bagus Wiksuana, Luh Gede Sri Artini. 2015. Pengaruh Nilai Tukar Rupiah Terhadap Return Saham Dengan Profitabilitas Sebagai Variabel Intervening. E-Jurnal Ekonomi dan Bisnis Universitas Udayana 4(04), 220-242.

Purba, E.M. dan Lisa M. 2012. Analisis Komparatif Rasio Keuangan. Antara PT. Hm Sampoerna, Tbk \& PT. Gudang Garam, Tbk.

Putra. 2016. Analisis Faktor-Faktor Yang Mempengaruhi Ekspor Tembakau Indonesia Ke Jerman. Economics Development Analysis Journal 2 (3), 1114.

Ramadaniar, Buyung, Topowijono dan Achmad Husaini. 2012. Analisis Rasio Keuangan Perbankan untuk Menilai Kinerja Keuangan Bank (Studi Pada PT. Bank Mandiri (Persero), Tbk. yang Listing Di BEI Untuk Periode Tahun 2009 - 2011). Jurnal. Fakultas Ilmu Administrasi Universitas Brawijaya, 1(1), 50-55.

Reinhardt, N. (2000) Back to Basics in Malaysia and Thailand: The Role of Resource-Based Exports in Their Export-Led Growth, World Development, 28(1), 57-77. 
Rinamenda Sinuraya. 2010. Analisa Pengaruh Pertumbuhan Ekonomi Terhadap Profitabilitas Perusahaan. Tesis Universitas Sumatera Utara.

Riyanto, Bambang. 2011. Dasar-dasar Pembelanjaan Perusahaan. Edisi ke 4. Yogyakarta: Yayasan Penerbit Gajah Mada.

Rivera, M. Juan. 1991. Prediction Performance of Earning Forecasts: The Case of U.S Multinationals. Journal of International Business Studies, 22(2), 1-7.

Rodriguez, Rita and Carter, E. Eugene. 2006. International Financial Management. Third Edition. New Jersey. Prentice-Hall International Edition.

Said, Mukhled, 2012. The Relationship between the ROA, ROE and ROI Ratios with Jordanian Insurance Public Companies Market Share Prices. International Journal of Humanities and Social Science, 2(11), 116-119.

Samimi, A., Ghobadi, N. (2016), Assessing deviation of the real exchange rate behavior-based assessment approach. Journal of Economic Policy, 8(15), $55-76$.

Samsul, Mohamad, 2006, Pasar Modal \& Manajemen Portofolio, Erlangga: Jakarta

Sartono, A. 2001. Manajemen Keuangan Internasional. BPFE: Yogyakarta.

Seiford, Lawrence M., and Joe Zhu. 1999. Profitability and Marketability of the top 55 US Commercial Banks. Management Science, 45(9), 1270-1288.

Simiyu, Christine Nanjala; Lessah Ngile. 2015. Effect Of Macroeconomic Variables On Profitability Of Commercial Banks Listed In The Nairobi Securities Exchange. International Journal of Economics, Commerce and Management, 3 (4), 1-16.

Siregar Hermanto, Arief Daryanto. 2005. Perkembangan dan Diversivikasi Ekspor Indonesia. Jurnal Manajemen dan Agribisnis, 2(2), 157-166.

Sugiyono. 2013. Metode Penelitian Pendidikan Pendekatan Kuantitatif, Kualitatif, dan R\&D. Bandung: Alfabeta.

Sukarno dan Syaichu. 2006. Analisis Faktor-Faktor Yang Mempengaruhi Kinerja Bank Umum Di Indonesia. Jurnal Studi Manajemen \& Organisasi, 13 (2), 46-58).

Sukirno, Sadono. 2008. 2009. Makro Ekonomi Teori Pengantar, PT. Raja Grafindo Persada, Jakarta 
Tambunan, Tulus. 2004. Perekonomian Indonesia : Teori dan Temuan Empiris. Jakarta : Ghalia Indonesia

Tiasita Meida, dan Wiagustini. 2017. "Studi Komparatif Kinerja Keuangan Pada Perusahaan Domestik dan Perusahaan multinasional di Bursa efek Indonesia". Jurnal Manajemen. 6(5), 2609 -2641.

Tulende Stevanus, Tommy Parengkuan, dan Van Rate Paulina. 2014. Pengaruh Nilai Tukar Rupiah Dan Fluktuasi Ihsg Terhadap Return On Asset Pada Industri Food And Beverage Yang Go Public Di Bursa Efek Indonesia. Jurnal EMBA, 2(4) 246-257.

Tuncay Ferhan Emir, Cengiz Hulya. 2017. "The Relationship between Corporate Profitability and Macroeconomic Indicators: Eviden from 500 Largest Industrial Organization in Turkey. International Bussines Research, 10(9), 88-90.

Wagner Joachim. 2011. Exports, imports and profitability: First evidence for manufacturing enterprises. Working Paper Series in Economics University of Lüneburg.

Wela Yulia Putra A.A, Ida Bagus Badjra. 2015. Pengaruh Leverage, Pertumbuhan Penjualan dan Ukuran Perusahaan Terhadap Profitabilitas. E-Jurnal Manajemen Unud, 4(7), 2052-2067.

Wiagustini, Ni luh Putu. 2010. 2014. Dasar - Dasar Manajemen Keuangan. Denpasar : Udayana University Press.

www.bps.co.id (diakses 18 desember 2017)

www.kemendag.go.id (diakses 25 desember 2017)

Zamanian Gholamreza, Mahmodpour Kamran, Yari Sepideh. 2017. Exchange Rate Uncertainty Effect on Export-Oriented Companies at Tehran Stock Exchange (Yield) Rate of Return: A Panel-Vector Autoregressive Model. International Journal of Economics and Financial Issues, 7(1), 207-213. 